\title{
A Private Conversation (Soukromý rozhovor)
}

\author{
Author: Hana Bořkovcová
}

First Published: 2004

About the Author: Hana Bořkovcová (born Knappová, 1927-2009) came from a Prague Czech-Jewish family. Her father worked as a businessman selling dental supplies. When the Nazis occupied Czechoslovakia, she was expelled from high school and attended a Jewish school. In 1942, Hana and her family were deported to the Theresienstadt Ghetto. She worked as an assistant teacher there. In the autumn of 1944, the family was transported to Auschwitz where her father and the younger brother were killed. Hana and her mother survived the selection and were taken to the labour camp in Kurzbach. Near the end of the war, they were sent on a death march. In the summer of 1945, they returned to Prague. After the war, Hana got married and raised five children. She converted to Catholicism. In 1964, some of Bořkovcová's short stories were published in literary journals. She published her first book in 1971 at the age of 44 and became a professional writer. In the 1970s and 1980s, she wrote novels and short stories for teenagers. After 1989, she returned to her Jewish roots and her experiences with the racial persecution during World War II.

Further Important Publications: Světýlka (Little Lights, 1971; short stories); Zakázané holky (1995, Forbidden Girls; novel for teens); Píšu a sešit mi leži na kolenou: deníky 1940-1944 (I'm Writing and the Notebook Is Lying on My Knees, ed. M. Kosák, 2011; diaries); Proč jsem nepsala všemi směry: výbor textů z let 1944-2009 (Why I Didn’t Write in All Directions, ed. H. Kosáková, 2015; short texts and poems).

\section{Content and Interpretation}

The story is based on autobiographical motifs. It describes the fate of an assimilated Jewish family from Prague starting from the 1930s. The unnamed narrator is the female protagonist of the story, the girl, later the young woman, mother and grandmother. The novel has an untraditional construction, a dialogue between the old and the young subjects of the narration.

"I'm the old woman sitting in the armchair here and now, you the girl on the bench somewhere far away in time...” (Bořkovcová, 2004, p. 5)

In the Polish literature, the same device is used in Wiesław Myśliwski's book The Needle's Ear (2018, Ucho igielne).

The novel of Bořkovcová presents two perspectives. The teenage girl describes actual experiences in her life: the well situated family in prewar Czechoslovakia, the persecution of the Jews during the Nazi occupation, Theresienstadt, Auschwitz (where her father and younger brother David are killed), labour camp, liberation and finally 
the beginning of her postwar life. The old narrator comments on these situations from a distance and concisely adds her later life events: her wedding, conversion to Christianity, children and grandchildren, and her literary writing.

The naive young girl depicts her childhood worries and troubles. She wishes her family were poor and did not have a housekeeper or cook and lived in a small oneroom flat where they would all be together. Her wish paradoxically comes true, after Adolf Hitler comes to power. For a young girl, Hitler's incomprehensible shouting on the radio embodies evil:

"Screaming horribly", you say so quietly. [...] "It was in German, but I still understood that he was yelling at us and he wanted to do something to us, even if I didn't know what it was and whether he could do it. Maybe he's crazy and they'll shut him up in a madhouse. But what if not?” (pp. 23-24)

Just as naive is her satisfaction at the beginning of the war. She knows that from now on, nobody can go abroad and the family will stay together.

A change in her mentality occurs after the deportation to Auschwitz and a few days later to a labour camp where women have to work in inhumane conditions. She becomes dazed and numb, she has frostbite on one of her feet and can't walk. From a thousand women, only a few survive, among them the girl and her mother.

Some hints are present in the novel, which are not clear for readers at first sight. For instance, before the war, her little brother David had surgery, they removed his adenoids. "He'll breathe well again", says his little sister happily (p. 65). Nevertheless, in Auschwitz in the gas chamber David's father is helpless, "Dad couldn't help him breathe" (p. 159).

Among other things, the narrator's relationship with her mother is of a great substance. Her mother helped her survive during the war, saving her life several times in the camps. She rescued her and other girls from being raped by Russian soldiers. After the war, they grew apart, the narrator gave up her Jewish faith and converted to Christianity.

\section{Main Topics and Problems}

Topics of the Holocaust and Jewish identity appear in some of Hana Bořkovcová's works. Nevertheless - except from the short stories in Little Lights (1971) - they were all published after 1989 or posthumously: besides of A Private Conversation, the novel for teens Forbidden Girls (1995) about the friendship of Jewish and Czech girls in the time of the Nazi occupation, Hana Bořkovcová's diaries from the war (2011) as well as some short texts and poems (2015).

One of the discriminatory orders for Jews during the war was the duty to wear a yellow star on their clothes (ordered in the Czech lands in the beginning of September, 1941). It is interesting that the girl narrator does not perceive it as a persecution. The Jewish star and Jewishness become an element of her identity of Jews and solidarity. 
We're all friends together. Also due to the stars. So we're going to the Jewish graveyard and if someone joins we will be certain belong to us, even if he or she is not from our class or from our school at all. With that star on their coat, they can’t belong to another place. (p. 94)

The following motifs can often be found in Holocaust literature. See Jiři Weil's $\rightarrow$ Life with a Star.

Other events and situations known from literary works or memories are also depicted in the Theresienstadt Ghetto: rats and lice, the hard fate of old people, census of ghetto inhabitants in Bohušovice Basin, theatre performances or the children of the Białystock Ghetto in Poland which are taken to Theresienstadt and are afraid to take a shower believing that these are gas chambers. See Josef Bor's $\rightarrow$ The Terezin Requiem or Norbert Frýd's A Message in the Bottle.

Key motifs in A Private Conversation are the belief in God and attitudes toward the Jews in society. During her experiences in the ghetto and the concentration camps, the girl narrator begins to be sceptical about God, His omnipotence and His existence at all. She asks the question how is it possible that God allows brutal killing and death of so many innocent victims, especially the Jews, his chosen people. See also Otto Weiss's $\rightarrow$ And God Saw That It Was Bad, Viktor Fischl's $\rightarrow$ Court Jesters; Emil Knieža's $\rightarrow$ The Sixth Battalion, On Guard!; Pavol Rankov's $\rightarrow$ It Happened on the First September (or Whenever). "After all, God cannot wish all of us to be shot. Or can He?" (p. 143) She refuses the blind obedience of some Orthodox Jews who declare it is God's will. Also the adult narrator asks these questions, with a distance of time and with new experiences of persecutions and genocides:

"I can only ask: Are You here? And more often: Where were You? Where are You? Because it continues the same what has been already. And it repeats. Even if we are not these who have to be finally solved now, by chance.” (p. 92)

The story captures the growing pressure on the Jews at the time of Nazi occupation. Along with it, the antisemitic behaviour of Czech people appears more often. On the other hand, other Czechs support their Jewish fellow citizens. For instance the school janitor or the classmate Mirka who is a Protestant. Even a German soldier who has to guard Jewish prisoners is moved by their appearance and helps Jewish women to carry heavy blocks of wood. Nevertheless, he is not present the next day, he has probably been punished and sent to the frontline.

After the war, on their way home, Jewish prisoners encounter an antisemitic Polish woman:

“- From a concentration camp? Jewesses? - she asks and you agree. - A few of you are coming back. The seemingly sympathetic woman shakes her head and adds: - And they could have left you all there.” (p. 201) 
On the contrary, the welcome at the Czech border is very nice. Czech friends return all their belongings they have left with them before the deportation and help them in the hard beginnings.

\section{Cited Work}

Bořkovcová, H. (2004). Soukromý rozhovor. Kostelní Vydří: Karmelitánské nakladatelství.

\section{Further References}

Holý, J. (2011). Židé a šoa v české a slovenské literatuře po druhé světové válce. In: J. Holý et al., eds., Šoa v české literatuře a v kulturní paměti. Praha: Akropolis, pp. 5051. Kosák, M. (2011). Komentáře. In: H. Bořkovcová, Pišu a sešit mi leži na kolenou. Praha: Plus, pp. 368-379. Kosáková, H. (2015). Cvaknutí, hranice, skok. In: H. Bořkovcová, Proč jsem jen nepsala všemi směry. Praha: Plus, pp. 249-253. Lukavec, J. (2004). Dvě vzdálené slupky cibule. Literârní noviny, 15(33), p. 33. Sladovníková, Š. (2016). Dětský pohled na holokaust. In: J. Holý, ed., Cizí i blízcí. Židé, literatura, kultura $v$ českých zemích ve 20. století. Praha: Akropolis, pp. 808-812. Urbanová, S. (2018). S holokaustem za zády: Téma holokaustu v české a překladové literatuře pro děti a mládež po roce 1989. Ostrava: Ostravská univerzita, pp. 111-114 and 157-163.

$\mathrm{JH}$ 